\title{
ОРГАНІЗАЦІЙНО-ПЕДАГОГІЧНІ УМОВИ ФОРМУВАННЯ ПРОФЕСІЙНОЇ КОМПЕТЕНЦІЇ МАЙБУТНІХ МЕДИЧНИХ СЕСТЕР У ПРОЦЕСІ ФАХОВОЇ ПІДГОТОВКИ (МЕТОДИЧНИЙ АСПЕКТ)
}

\author{
Т. Рудницька, Л. Чорнобрива \\ Відокремлений підрозділ “Рокитнівський фаховий медичний коледж» \\ комунального закладу вищої освіти “Рівненська медична академія" \\ Рівненської обласної ради»
}

У статті обгрунтовано організаційно-педагогічні умови формування професійної компетентності фахівців - майбутніх медичних сестер, що забезпечують інтегроване викладання загальнопрофесійних i спеціальних медичних дисциплін з урахуванням становлення і розвитку особистісних якостей, усвідомленого відповідального ставлення до обраної спеціальності.

\section{ORGANIZATIONAL AND PEDAGOGICAL CONDITIONS OF THE FORMING OF THE PROFESSIONAL COMPETENCE OF FUTURE NURSES IN THE PROFESSIONAL PROCESS (METHODICAL ASPECT)}

\author{
T. Rudnytska, L. Chornobryva \\ Rokytne Medical College of Rivne Medical Academy
}

\begin{abstract}
The article substantiates the organizational and pedagogical conditions, the formation of professional competence of specialists - future nurses, providing integrated teaching of general and special medical disciplines, taking into account the formation and development of personal qualities, conscious responsible attitude to the chosen specialty.
\end{abstract}

Вступ. Забезпечення якості медсестринської допомоги як одне з провідних завдань охорони здоров'я нерозривно пов'язане з професійною підготовкою кваліфікованих фахівців сестринських служб і реалізацією всіх потенційних можливостей і здібностей особистості.

Розвиток системи професійної підготовки медичних працівників $\epsilon$ важливим питанням сьогодення. За сучасних умов докорінно змінився підхід до підготовки медичних сестер, який вимагає створення таких організаційно-педагогічних умов, що дозволяють формувати глибокі теоретичні знання, професійно важливі якості, готовність до придбання багатофункціональних умінь, що забезпечують їхню професійну мобільність, оволодіння новими сестринськими технологіями. Науковці наголошують на важливості проблеми формування професійної компетентності медичних сестер і пропонують звернути увагу на систему підготовки спеціалістів сестринської справи з урахуванням перспектив розвитку потреб охорони здоров'я.

Підготовка особистості майбутнього фахівця і формування професійної компетентності в стінах медичного інституту $є$ об'єктивною потребою.

Основна частина. Професійна компетентність медичної сестри являє собою системоутворювальний фактор професійної підготовки і майбутньої професійної діяльності фахівця, який забезпечується синтезом професійних знань, умінь і визначає готовність його до професійної діяльності та подальшого професійного зростання.

Під професіоналізмом медичної сестри варто розуміти інтегративну ознаку, що поєднує високий рівень професійної компетентності й техніки проведення медсестринських процедур та маніпуляцій; культуру спілкування, відповідальність, надійність, толерантність, емпатійність; здатність орієнтуватися і приймати рішення в екстремальних клінічних ситуаціях.

(ㄱ Т. Рудницька, Л. Чорнобрива, 2020 
Вищі медичні навчальні заклади готують випускників як соціальних особистостей, здатних вирішувати певні проблеми і завдання діяльності за умови оволодіння системою умінь та компетенцій.

Медична сестра повинна володіти такими компетенціями, як:

- мовно-соціальна адаптація;

- соціально-особистісні навички;

- загальнонаукові;

- інструментальні;

- спеціалізовано-професійні.

У процесі фахової підготовки підвищенню ефективності процесу формування основ професіоналізму майбутніх медичних сестер сприяють такі організаційно-педагогічні умови, як: оновлення підготовки майбутніх медичних сестер через впровадження інноваційних освітніх технологій та інтерактивних методів навчання; створення професійно орієнтованого освітнього середовища шляхом адаптації його до специфіки фахової діяльності медичної сестри; удосконалення педагогічної майстерності викладачів-клініцистів засобами науково-методичної роботи; активізація процесу формування практичних умінь та навичок медичних сестер через імітаційне моделювання у квазіпрофесійній діяльності [1].

У дослідженні І. В. Радзієвської виділено чотири рівні розвитку професійної компетентності студентів:

1-й рівень - студент засвоїв певний обсяг знань, здатний довільно відтворити свої думки, усвідомив необхідність подальшого їх використання для вирішення проблем у практичній галузі знань;

2-й рівень - студент набуває вміння і навичок у вирішенні ситуаційних завдань, сформульованих викладачем, використовуючи отримані знання (клініка захворювань, принципи, правила догляду і лікування за хворими та ін.);

3-й рівень - студент набуває вміння самостійного пошуку вирішення поставленого викладачем перед ним ситуаційного завдання, використовуючи наявні знання, досвід (сестринське обстеження пацієнта);

4-й рівень - студент набуває вміння самостійно сформулювати технологічні завдання, здійснювати вибір вихідних даних для вирішення проблемної ситуації, поставленої викладачем, використовуючи знання, вміння, навички, набуті під час вивчення спеціальних дисциплін (сестринське обстеження пацієнта із заповненням карти спостереження при різній патології) [2].
Перехід на якісно новий рівень підготовки професійних медсестринських кадрів можливий за допомогою впровадження в педагогічну практику активних форм навчання. Активні методи навчання поділяють на неімітаційні та імітаційні.

Неімітаційні методи включають проблемну лекцію, проблемно-активні практичні та лабораторні заняття, самостійне курсове проектування та ін. (орієнтовані на проблемність, інтенсифікацію логіко-пізнавальної діяльності студентів).

Імітаційні методи (імітація реальних обставин в умовній ситуації) поділяють на неігрові та ігрові. До неігрових імітаційних методів належать метод конкретних ситуацій, імітаційні вправи, індивідуальний технологічний тренінг на автоматизованих робочих місцях. Сутність зазначених методів полягає в моделюванні реальних об'єктів і ситуацій без наявності вільної гри і виконання рольових функцій. До ігрових імітаційних методів належать ділові ігри, ігрове виробниче проектування, метод розігрування ролей. Вони ґрунтуються на ігровій функціональній основі, ігрових елементах, зв'язках, стосунках. В ігрових методах поєднуються два принципи навчання: принцип проблемності та принцип моделювання майбутньої професійної діяльності.

Імітаційне моделювання - метод, що дозволяє будувати моделі, операції, ситуації, що описують процеси так, як вони проходили 6 у дійсності. Таку модель можна «програти» в часі для одного чи більше випробувань. При цьому результати відпрацьованих імітацій буде визначати комп'ютер. Впровадження симуляційної технології навчання дає можливість придбати необхідні практичні та теоретичні знання, не завдаючи шкоди здоров'ю людини. При цьому система навчання побудована на методі отримання знань від простого до складного: починаючи з простих маніпуляцій, закінчуючи відпрацюванням дій в імітованих клінічних ситуаціях.

Розроблено шляхи формування професійної компетентності майбутніх медичних сестер у сестринській справі засобами інтегрованого викладання загальних і спеціальних дисциплін. Увагу студентів акцентовано на створенні проблемних ситуацій під час лекцій та семінарських занять зі застосуванням практичних історій хвороб, амбулаторних карт пацієнтів, використанням методів вирішення ситуаційних завдань, проведенням ділових, рольових ігор, конкурсів, конференцій, брейн-рингів з клінічних дисциплін, підго- 
товкою і захистом сестринських карт спостереження за пацієнтами.

Неігрові методи представлені методами рішення і самостійного проектування ситуаційних завдань і проблемних ситуацій, аналізу конкретних ситуацій, кейс-методом, вправами-діями за інструкцією. Ігрові методи включають: імітацію діяльності на тренажерах, розігрування ситуацій, застосування рольових, організаційно-діяльнісних, ділових ігор, стажування 3 виконанням функціональних обов'язків, модерацію. Заняття проводять в кабінетах доклінічної практики та центрі практичних маніпуляцій, які обладнані зі створенням умов для професійного середовища (процедурний кабінет, перев'язочна, операційна, палата інтенсивної терапії), де і відбувається оволодіння квазіпрофесійною діяльністю [3].

Процес формування професійної компетентності майбутніх медичних сестер буде більш ефективним, якщо:

- створені організаційно-педагогічні умови, що забезпечують інтегроване викладання загальнопрофесійних і спеціальних медичних дисциплін 3 урахуванням становлення і розвитку в студентів особистісних якостей, усвідомленого відповідального ставлення до обраної спеціальності;

- забезпечена практично-орієнтована спрямованість навчально-виховного процесу з використанням комплексу активних форм і методів професійної підготовки;

- сформовані необхідні професійно-практичні вміння та навички за фахом з оволодінням комунікативних здібностей, з розвитком клінічного мислення, з прищепленням умінь працювати в команді.

Висновки. Створення необхідних організаційнопедагогічних умов формування професійної компетентності фахівців - майбутніх медичних сестер $\epsilon$ одним із найважливіших напрямків розвитку сестринської справи. Симуляційні форми навчання для напрацювання практичних навичок особливо затребувані в професійній підготовці сестринського персоналу, бо дозволяють підвищити компетентність майбутніх медсестер, а також забезпечити ефективність і якість медичної допомоги.

сестринского персонала / Е. А. Кадникова // Журнал МедиАль. - 2010. - № 9. - С. 34-36.

3. Радзієвська І. В. Формування професійної компетентності медичних сестер / І. В. Радзієвська // Проблеми освіти : зб. наук. пр. - 2008. - Вип. 57. - С. 69-73. учебного процесса при профессиональной подготовке 